\title{
TabuTémák -
}

\section{társadalmi nem, szexuális orientáció és fogyatékosság}

\author{
Szerkesztői előszó a Gyermeknevelés Online Tudományos Folyóirat 2016/3 \\ számhoz
}

A társadalmi nemek kutatása több évtizede vált vezető témává a társadalom- és irodalomtudományok területén. A pszichológia tudományterületén belüli térnyerése után lassan a pedagógia tudományát is meghódítja a genderszemlélet. Ennek a megközelítésnek a szellemében válogattuk össze jelen számunk tanulmányait, természetesen nem célozva a tématerület teljességének lefedését, mivel az enciklopédiákat töltene meg. Tematikus számunk témakörei a viszonylag erős empirikus megalapozottsággal bíró nemisztereotípia-kutatástól kiindulva haladnak a sokkal több vitát kiváltó nemi identitás- és szexuálisorientáció-variációk tárgyalásán keresztül olyan interdiszciplináris témákig, mint a fogyatékossággal élő vagy egyéb okból sajátos nevelési igényű gyermekek nemi identitása és szexuális nevelése.

Kalcsó Réka és F. Lassú Zsuzsa tanulmánya a nemi sztereotípiák vizsgálatát célzó empirikus kutatás eredményeit összegezi, összevetve a 2015-ben, óvodás gyermekekkel végzett kutatás eredményeit régebbi sztereotípiakutatásokkal. Tanulmányukban az óvodapedagógus nemét, mint fontos sztereotípia-alakító tényezőt feltételezték, melyet ugyan nem erősítettek meg eredményeik, azonban azok továbbgondolása lényeges pedagógiai kérdéseket, fejlesztési lehetőségeket vet fel.

Ilyen pedagógiai lehetőség a tematikus rovat második tanulmányában tárgyalt nemisztereotípia-ellenes svéd pedagógiai gyakorlat, illetve az ezzel párhuzamba állított, elsősorban az Egyesült Államokban elterjedt nemileg szegregált oktatás (F. Lassú, jelen szám). Mindkét országban a nemi esélyegyenlőség növelése a cél, melyet más eszközökön keresztül kívánnak elérni - ezeket mutatja be a tanulmány, felvetve a hazai genderpedagógiai kezdeményezések szükségességét is.

A skandináv országok a nemi esélyegyenlőség minden területén elöl járnak, így a szexuális kisebbségekkel szembeni megítélés, antidiszkriminatív gyakorlat, nemi nevelés és érzékenyítés témakörében is. A legtöbb országban azonban a többségitől eltérő nemi identitás és szexuális orientáció tabuként kezelt, láthatatlan és elnyomott közösségekbe száműzött „magánügy”, melyet a gyermeknevelés területén végképp elhallgatunk. Főglein Karola tanulmánya a transznemüség témakörébe vezeti be az olvasót, megnyitva ezzel a témáról való nyílt és elfogadó gondolkodás lehetőségét a gyermeknevelés területén is. Írása a kapcsolódó legfontosabb fogalmak és elméleti modellek tisztázásával, a kapcsolódó nevelési és társadalmi kérdések felvetésével segíti a szülők és nevelők tájékozódását ezen a kevéssé ismert területen.

Hazánkban is folyó, ideológiai vonatkozásoktól sem mentes vitába kapcsolódik be Román Boglárka tanulmányával a homoszexualitáshoz kapcsolódó konverziós és affirmatív terápiák bemutatásával. Írásában röviden áttekinti a homoszexualitást magyarázó megközelítéseket is, noha hangsúlyozza azok irreleváns voltát az elfogadás, esélyegyenlőség, diszkriminációmentes viszonyulás megteremtésével kapcsolatban. Az egymással ellentétes terápiás megközelítések hatékonyságát bemutató kutatási eredmények összegzése mellett célja elsősorban a szülők és nevelők érzékenyítése, az elfogadó attitűd növelése. 
Ha van terület, amely a szexualitás és nemi nevelés tekintetében még inkább elhallgatott, az a fogyatékossággal élő személyek nemi fejlődése, szexuális egészsége és nemi önrendelkezése. Zechmeister Andrea tanulmánya ezt a tabuként kezelt területet tárgyalja, és mutatja be a kérdéshez kapcsolódó legfontosabb hazai és nemzetközi eredményeket, megközelítéseket, valamint saját iskolájának jó gyakorlatát. Mivel a többségi pedagógia vonatkozásában sincs túl sok ilyen jó gyakorlat, ezért a tanulmányban ismertetett kezdeményezés példaértékü lehet.

Szintén a sajátos nevelési igény és a nemi fejlődés metszéspontjában készült Lukács Szandra tanulmánya, amely egy kismintás kutatás eredményein keresztül tárgyalja a nemi identitás fejlödése és az autizmus spektrumzavar összefüggését. Az autizmus spektrumzavar kialakulásának okairól, hasonlóan a többségitől eltérő szexuális orientáció kialakulásához, számos tudománytalan, de sokat idézett magyarázat vált ismertté, ezért különösen fontos, hogy a tudományterületen született bizonyítékokon alapuló magyarázatok a lehető legtöbb fórumon megjelenjenek, elérve szülőkhöz, nevelőkhöz.

A tematikus szám hat tanulmánya a teljesség igénye nélkül kínál izgalmas betekintést egy kevéssé tárgyalt tématerület pedagógiai, gyógypedagógiai és pszichológiai vonatkozásaiba, elindítva és folytatva a neveléstudományi szakemberek, szülők és nevelök szakmai tudásának mélyítését.

F. Lassú Zsuzsa 